\title{
Clostridium difficile ribotypes in humans and animals in Brazil
}

\author{
Rodrigo Otávio Silveira Silva ${ }^{1 /+}$, Maja Rupnik ${ }^{2,3,4}$, Amanda Nádia Diniz¹, \\ Eduardo Garcia Vilela ${ }^{5}$, Francisco Carlos Faria Lobato ${ }^{1}$ \\ 1Universidade Federal de Minas Gerais, Escola de Veterinária, Belo Horizonte, MG, Brasil \\ ${ }^{2}$ University of Maribor, Faculty of Medicine, Maribor, Slovenia ${ }^{3}$ National Laboratory for Health, Environment and Food, Maribor, Slovenia \\ ${ }^{4}$ Center of Excellence for Integrated Approaches in Chemistry and Biology of Proteins, Ljubljana, Slovenia \\ ${ }^{5}$ Universidade Federal de Minas Gerais, Faculdade de Medicina, Belo Horizonte, MG, Brasil
}

\begin{abstract}
Clostridium difficile is an emerging enteropathogen responsible for pseudomembranous colitis in humans and diarrhoea in several domestic and wild animal species. Despite its known importance, there are few studies about C. difficile polymerase chain reaction (PCR) ribotypes in Brazil and the actual knowledge is restricted to studies on human isolates. The aim of the study was therefore to compare C. difficile ribotypes isolated from humans and animals in Brazil. Seventysix C. difficile strains isolated from humans $(n=25), \operatorname{dogs}(n=23)$, piglets $(n=12)$, foals $(n=7)$, calves $(n=7)$, one cat, and one manned wolf were distributed into 24 different PCR ribotypes. Among toxigenic strains, PCR ribotypes 014/020 and 106 were the most common, accounting for 14 (18.4\%) and eight (10.5\%) samples, respectively. Fourteen different PCR ribotypes were detected among human isolates, nine of them have also been identified in at least one animal species. PCR ribotype 027 was not detected, whereas 078 were found only in foals. This data suggests a high diversity of PCR ribotypes in humans and animals in Brazil and support the discussion of $\mathrm{C}$. difficile as a zoonotic pathogen.
\end{abstract}

Key words: C. difficile - pseudomembranous colitis - zoonosis

Clostridium difficile is an emerging enteropathogen responsible for most cases of pseudomembranous colitis in humans and diarrhoea in several animal species (Songer 2010). In the last years, studies showed a high similarity between $C$. difficile isolates from humans and animals, suggesting a possible zoonotic transmission (Hensgens et al. 2012).

There are few studies about $C$. difficile polymerase chain reaction (PCR) ribotypes in Brazil and the actual knowledge is restricted to studies on human isolates in the state of Rio de Janeiro (Balassiano et al. 2012). Studies showed a high prevalence of $C$. difficile infection (CDI) in piglets and there are reports also in foals, dogs, and wild animals in Brazil (Cruz Junior et al. 2013, Silva et al. 2013a, b, 2014a), but the $C$. difficile PCR ribotypes in domestic animals are still unknown. The aim of the study was therefore to compare $C$. difficile ribotypes isolated from humans and animals in Brazil.

Seventy-six $C$. difficile isolates from humans $(\mathrm{n}=$ $25)$, dogs $(n=23)$, piglets $(n=12)$, foals $(n=7)$, calves $(\mathrm{n}=7)$, one cat, and one manned wolf isolated in between 2008 and 2015 were included (Table I). Human samples were collected from inpatients with suspicious CDI from the University Hospital of the Federal Univer-

doi: 10.1590/0074-02760150294

Financial support: CNPq, FAPEMIG, CAPES, PRPq-UFMG, INCTPecuária

+ Corresponding author: rodrigo.otaviosilva@gmail.com

Received 5 August 2015

Accepted 11 November 2015 sity of Minas Gerais (UFMG) (Silva et al. 2014c). The samples from diarrhoeic dogs, foals, calves, and maned wolf (Chrysocyon brachyurus) were obtained directly from the rectum, at the Veterinary Hospital of UFMG at the time of the consultation, and were only collected from animals for which the main motivation for the consultation was the occurrence of diarrhoea (Silva et al. 2013a, b). Samples from apparently healthy dogs and one healthy cat, belonging to students from the university, were collected at the time of defecation (Silva et al. 2013a). The piglets included in this study were submitted to the Veterinary School of UFMG for routine diagnosis of piglet neonatal diarrhoea (Cruz-Junior et al. 2013). A/B toxins were detected by cytotoxicity assay (Silva et al. 2013b) or with a commercial ELISA kit (C. difficile Tox A/B II; Techlab Inc, USA). All procedures were previously approved by the Research Ethical Committee of UFMG (CAAE - 0710.0.203.0000.11).

Intergenic spacer regions were amplified using Bidet primers as previously described (Janezic \& Rupnik 2010). PCR ribotypes for which the reference strains were available are designated by international Cardiff/ Leeds nomenclature, while others are designated by internal nomenclature (SLO and number).

The Table II summarises the PCR ribotypes and clinical history of the $C$. difficile strains included in this study. Twenty-four PCR ribotypes were identified, where 014/020, 009, and 106 were the most common, accounting for 14 (18.4\%), 13 (17.1\%) and eight (10.5\%) samples, respectively. Fourteen different PCR ribotypes were detected among human isolates; nine of them have also been identified in at least one animal species. This data support the discussion of $C$. difficile as a zoonotic pathogen. Also, the present study is the first to report the isolation of $C$. difficile strains positive for binary toxin gene $(c d t B)$ in humans in Brazil. 
TABLE I

Distribution by host and clinical details from 76 Clostridium difficile isolates from humans and animals in Brazil

\begin{tabular}{|c|c|c|c|}
\hline Host & Clinical history & $\begin{array}{c}\text { Isolates } \\
\text { n (\%) }\end{array}$ & $\begin{array}{l}\text { Total } \\
\text { n (\%) }\end{array}$ \\
\hline \multirow[t]{2}{*}{ Humans } & CDI & $20(26.3)$ & $25(32.9)$ \\
\hline & Diarrhoeic but negative for A/B toxin & $5(6.6)$ & \\
\hline \multirow[t]{3}{*}{ Dogs } & CDI & $2(2.6)$ & $23(30.3)$ \\
\hline & Diarrhoeic but negative for $\mathrm{A} / \mathrm{B}$ toxin & $16(21)$ & \\
\hline & Not diarrhoeic & $5(6.6)$ & \\
\hline \multirow[t]{3}{*}{ Piglets } & CDI & $8(10.5)$ & $12(15.8)$ \\
\hline & Diarrhoeic but negative for A/B toxin & $3(3.9)$ & \\
\hline & Not diarrhoeic & $1(1.3)$ & \\
\hline \multirow[t]{2}{*}{ Foal } & CDI & $4(5.3)$ & $7(9.2)$ \\
\hline & Diarrhoea & $3(3.9)$ & \\
\hline Calves & Diarrhoea & $8(10.5)$ & $8(10.5)$ \\
\hline Cat & Not diarrhoeic & $1(1.3)$ & $1(1.3)$ \\
\hline Maned wolf & Diarrhoeic but negative for A/B toxin & $1(1.3)$ & $1(1.3)$ \\
\hline
\end{tabular}

CDI: C. difficile infection.

PCR ribotype 014/020 was previously reported in three humans with confirmed CDI (Balassiano et al. 2009, Secco et al. 2014) and in free-living coatis (Nasua nasua) in an urban park in Brazil (Silva et al. 2014b). At this time, it was again detected in four hospitalised humans with confirmed CDI. Moreover, the PCR ribotype $014 / 020$ was also found in six dogs, three piglets, and in one foal, four of them with CDI, which suggest a high frequency of this PCR ribotype in humans and animals in Brazil. PCR ribotype 014/020 is currently the main cause of CDI in the European community and has been reported in animals in several countries including Germany, Netherlands, United States of America, and Slovenia (Bauer et al. 2011, Janezic et al. 2012, 2014). Thus, the present study corroborates previous reports that showed PCR ribotype 014/020 can colonise a broader range of species and also it is present in different geographic regions, although this type is not recognised as being hypervirulent (Janezic et al. 2014).

Among toxigenic strains, PCR ribotype 106 was the second most frequent in this study. Until 2009, PCR ribotype 106 was reported only in the United Kingdom when then it was identified in one human with CDI (Balassiano et al. 2009) in Brazil and recently detected also in coatis (Silva et al. 2014b). In the present study, 106 has been identified in humans (4 isolates) and dogs (4 isolates), suggesting that this PCR ribotype might be common in humans and also in animals in the country.

The PCR ribotype 009 (also known as 53-like) was the second most common in the present study. This type was found in $13(17.1 \%)$ isolates, one from human and four from different animal species, which corroborates previous studies (Janezic et al. 2012) and suggest that this PCR ribotype, similar to $014 / 020$, is common and might have a high capacity to colonise different species. Among eight isolates from calves, five were classified as PCR ribotype 009. Considering that the strains were isolated from calves between 10-60 days of age from five different farms, the present result suggest a low diversity in this group compared with the other species or with previous studies with strains from calves (Janezic et al. 2012, 2014, Koene et al. 2012, Knight et al. 2013). Finally, it is also interesting to note that recent studies have shown that nontoxigenic strains has a potential to prevent CDI in humans and piglets (Songer et al. 2007, Oliveira Junior et al. 2016, Zhang et al. 2015). Considering that the nontoxigenic ribotype 009 has a high capacity to colonise different species, this may be a good candidate for future studies focusing on CDI prevention by colonisation with nontoxigenic strains.

Some PCR ribotypes previously reported in humans in Brazil (Balassiano et al. 2009, 2010, 2011) were not identified in the present study, including PCR ribotypes 038, 133, 135, and 233. Together with the present report, these results suggest a high diversity of PCR ribotypes in humans and animals in Brazil, similar to previously reported in other countries. Moreover, the prevalence of some PCR ribotypes appears to vary in different geographical regions. Also, the present study is the first to report the isolation of $c d t B$ in humans in Brazil.

It is remarkable that some common PCR ribotypes in Europe and North America, such as 002, 015, 045, and 150 , seem to be rare in Brazil. Recently, some reports suggest the rapid emergence of the epidemic 027 strain in Latin America, with confirmed cases in Costa Rica, Panama, and Chile (Hernández-Rocha et al. 2012, QuesadaGómez et al. 2012, López-Ureña et al. 2014). Anyway, this $C$. difficile ribotype is still not reported in animals and humans in Brazil. PCR ribotypes 078 has also drawn the attention of researchers for its increased frequency in cases in humans and/or animals (Hensgens et al. 2012). Again in contrast with these findings, 078 were found 
TABLE II

Ribotypes and host clinical details from 76 Clostridium difficile isolates from humans and animals in Brazil

\begin{tabular}{|c|c|c|c|c|}
\hline Ribotype & & $\begin{array}{c}\text { Total isolates } \\
\mathrm{n}(\%)\end{array}$ & Host & $\begin{array}{c}\text { Clinical history } \\
\text { (number of isolates) }\end{array}$ \\
\hline $001 / 072$ & $\mathrm{~A}^{+} \mathrm{B}^{+} \mathrm{CDT}^{-}$ & $3(3.9)$ & $\begin{array}{l}\text { Human } \\
\text { Piglet }\end{array}$ & $\begin{array}{c}\text { CDI (2) } \\
\text { Not diarrhoeic (1) }\end{array}$ \\
\hline 009 & $\mathrm{~A}^{-} \mathrm{B}^{-} \mathrm{CDT}^{-}$ & $13(17.1)$ & $\begin{array}{l}\text { Human } \\
\text { Dog } \\
\text { Cat } \\
\text { Calf } \\
\text { Foal }\end{array}$ & $\begin{array}{c}\text { Diarrhoea (1) } \\
\text { Diarrhoea (3) } \\
\text { Not diarrhoeic (2) } \\
\text { Not diarrhoeic (1) } \\
\text { Diarrhoea (5) } \\
\text { Diarrhoea (1) }\end{array}$ \\
\hline 010 & $\mathrm{~A}^{-} \mathrm{B}^{-} \mathrm{CDT}^{-}$ & $3(3.9)$ & $\begin{array}{l}\text { Human } \\
\text { Dog }\end{array}$ & $\begin{array}{l}\text { Diarrhoea (1) } \\
\text { Diarrhoea (2) }\end{array}$ \\
\hline 011/049 & $\mathrm{A}^{+} \mathrm{B}^{+} \mathrm{CDT}^{-}$ & $1(1.3)$ & Piglet & Diarrhoea (1) \\
\hline 012 & $\mathrm{~A}^{+} \mathrm{B}^{+} \mathrm{CDT}^{-}$ & $3(3.9)$ & Piglet & CDI (3) \\
\hline $014 / 020$ & $\mathrm{~A}^{+} \mathrm{B}^{+} \mathrm{CDT}^{-}$ & $14(18.4)$ & $\begin{array}{l}\text { Human } \\
\text { Dog }\end{array}$ & $\begin{array}{c}\text { CDI (4) } \\
\text { CDI (2) } \\
\text { Diarrhoea (3) } \\
\text { Not diarrhoeic (1) } \\
\text { CDI (1) } \\
\text { Diarrhoea (2) }\end{array}$ \\
\hline & & & Foal & CDI (1) \\
\hline $050(\mathrm{CE})$ & $\mathrm{A}^{+} \mathrm{B}^{+} \mathrm{CDT}^{-}$ & $1(1.3)$ & Human & Diarrhoea (1) \\
\hline 053 & $\mathrm{~A}^{-} \mathrm{B}^{-} \mathrm{CDT}^{-}$ & $4(5.3)$ & $\begin{array}{l}\text { Dog } \\
\text { Calf } \\
\text { Foal }\end{array}$ & $\begin{array}{l}\text { Diarrhoea (2) } \\
\text { Diarrhoea (1) } \\
\text { Diarrhoea (1) }\end{array}$ \\
\hline $\begin{array}{l}078 \\
084(\mathrm{CE})\end{array}$ & $\mathrm{A}^{+} \mathrm{B}^{+} \mathrm{CDT}^{+}$ & $\begin{array}{l}3(3.9) \\
1(1.3)\end{array}$ & $\begin{array}{c}\text { Foal } \\
\text { Piglet }\end{array}$ & $\begin{array}{l}\text { CDI (3) } \\
\text { CDI (1) }\end{array}$ \\
\hline 106 & $\mathrm{~A}^{+} \mathrm{B}^{+} \mathrm{CDT}^{-}$ & $8(10.5)$ & Human & $\begin{array}{c}\text { CDI (3) } \\
\text { Diarrhoea (1) } \\
\text { Diarrhoea (3) } \\
\text { Not diarrhoeic (1) }\end{array}$ \\
\hline 126 & $\mathrm{~A}^{+} \mathrm{B}^{+} \mathrm{CDT}^{+}$ & $2(2.6)$ & Piglet & CDI (2) \\
\hline 131 & $\mathrm{~A}^{+} \mathrm{B}^{+} \mathrm{CDT}^{-}$ & $1(1.3)$ & Human & CDI (1) \\
\hline $602(\mathrm{CE})$ & $\mathrm{A}^{+} \mathrm{B}^{+} \mathrm{CDT}^{-}$ & $1(1.3)$ & Dog & Diarrhoea (1) \\
\hline SLO002 & $\mathrm{A}^{-} \mathrm{B}^{-} \mathrm{CDT}^{-}$ & $6(7.9)$ & $\begin{array}{c}\text { Human } \\
\text { Dog } \\
\text { Maned wolf }\end{array}$ & $\begin{array}{l}\text { Diarrhoea (4) } \\
\text { Diarrhoea (1) } \\
\text { Diarrhoea (1) }\end{array}$ \\
\hline SLO046 & $\mathrm{A}^{+} \mathrm{B}^{+} \mathrm{CDT}^{-}$ & $1(1.3)$ & Piglet & CDI (1) \\
\hline SLO147 & $\mathrm{A}^{+} \mathrm{B}^{+} \mathrm{CDT}^{-}$ & $2(2.6)$ & $\begin{array}{c}\text { Human } \\
\text { Foal }\end{array}$ & $\begin{array}{c}\text { CDI (1) } \\
\text { Diarrhoea (1) }\end{array}$ \\
\hline SLO179 & $\mathrm{A}^{-} \mathrm{B}^{-} \mathrm{CDT}^{-}$ & $1(1.3)$ & Calf & Diarrhoea (1) \\
\hline SLO197 & $\mathrm{A}^{+} \mathrm{B}^{+} \mathrm{CDT}^{+}$ & $1(1.3)$ & Human & CDI (1) \\
\hline SLO198 & $\mathrm{A}^{+} \mathrm{B}^{+} \mathrm{CDT}^{+}$ & $2(2.6)$ & $\begin{array}{l}\text { Human } \\
\text { Calf }\end{array}$ & $\begin{array}{c}\text { CDI (1) } \\
\text { Diarrhoea (1) }\end{array}$ \\
\hline SLO199 & $\mathrm{A}^{+} \mathrm{B}^{+} \mathrm{CDT}^{-}$ & $2(2.6)$ & $\begin{array}{l}\text { Human } \\
\text { Dog }\end{array}$ & $\begin{array}{c}\text { CDI (1) } \\
\text { Diarrhoea (1) }\end{array}$ \\
\hline SLO224 & $\mathrm{A}^{+} \mathrm{B}^{+} \mathrm{CDT}^{+}$ & $1(1.3)$ & Human & CDI (1) \\
\hline SLO225 & $\mathrm{A}^{+} \mathrm{B}^{+} \mathrm{CDT}^{-}$ & $1(1.3)$ & Human & Diarrhoea (1) \\
\hline SLO231 & $\mathrm{A}^{+} \mathrm{B}^{+} \mathrm{CDT}^{+}$ & $1(1.3)$ & Dog & Not diarrhoeic (1) \\
\hline
\end{tabular}

CDI: C. difficile infection. 
only in three foals (4\%) with confirmed CDI. The present study suggests that Brazil has some marked differences in the pattern of $C$. difficile ribotypes in humans and animals compared to those reported in the rest of the world. Anyway, considering the continental dimensions of the country and the limited number of isolates evaluated, these results should be analysed cautiously.

This is the first study to evaluate $C$. difficile strains from domestic animals in Brazil and shows a high diversity of PCR ribotypes, also with a considerable number of ribotypes present in both humans and various domestic animals.

\section{ACKNOWLEDGEMENTS}

To A Kocuvan and Tanja Rikanovic, for contribution to PCR ribotyping.

\section{REFERENCES}

Balassiano IT, Dos Santos-Filho J, de Oliveira MP, Ramos MC, Japiassu AM, Dos Reis AM, Brazier JS, de Oliveira Ferreira E, Domingues RM 2010. An outbreak case of Clostridium difficile-associated diarrhea among elderly inpatients of an intensive care unit of a tertiary hospital in Rio de Janeiro, Brazil. Diagn Microbiol Infect Dis 68: 449-455.

Balassiano IT, dos Santos-Filho J, Vital-Brazil JM, Nouér SA, Souza CR, Brazier JS, Ferreira E de O, Domingues RM 2011. Detection of cross-infection associated to a Brazilian PCR-ribotype of Clostridium difficile in a university hospital in Rio de Janeiro, Brazil. Antonie Van Leeuwenhoek 99: 249-255.

Balassiano IT, Miranda KR, Boente RF, Pauer H, Oliveira IC, SantosFilho J, Amorim EL, Caniné GA, Souza CF, Gomes MZ, Ferreira EO, Brazier JS, Domingues RM 2009. Characterization of Clostridium difficile strains isolated from immunosuppressed inpatients in a hospital in Rio de Janeiro, Brazil. Anaerobe 15: 61-64.

Balassiano IT, Yates EA, Domingues RM, Ferreira EO 2012. Clostridium difficile: a problem of concern in developed countries and still a mystery in Latin America. J Med Microbiol 61: 169-179.

Bauer MP, Notermans DW, van Benthem BH, Brazier JS, Wilcox MH, Rupnik M, Monnet DL, van Dissel JT, Kuijper EJ, ECDIS Study Group 2011. Clostridium difficile infection in Europe: a hospital-based survey. Lancet 377: 63-73.

Cruz Junior EC, Salvarani FM, Silva ROS, Silva MX, Lobato FCF, Guedes RMC 2013. A surveillance of enteropathogens in piglets from birth to seven days of age in Brazil. Braz J Vet Res 33: 963-969.

Hensgens MP, Keessen EC, Squire MM, Riley TV, Koene MG, de Boer E, Lipman LJ, Kuijper EJ, European Society of Clinical Microbiology and Infectious Diseases Study Group for Clostridium difficile (ESGCD) 2012. Clostridium difficile infection in the community: a zoonotic disease? Clin Microbiol Infect 18: 635-645.

Hernández-Rocha C, Barra-Carrasco J, Pizarro-Guajardo M, Ibáñez P, Bueno SM, Sarker MR, Guzman AM, Alvarez-Lobos M, Paredes-Sabja D 2012. Epidemic Clostridium difficile ribotype 027 in Chile. Emerg Infect Dis 18: 1370-1372.

Janezic S, Ocepek M, Zidaric V, Rupnik M 2012. Clostridium difficile genotypes other than ribotype 078 that are prevalent among human, animal and environmental isolates. BMC Microbiol 12: 48.

Janezic S, Zidaric V, Pardon B, Indra A, Kokotovic B, Blanco JL, Seyboldt C, Diaz CR, Poxton IR, Perreten V, Drigo I, Jiraskova A, Ocepek M, Weese JS, Songer JG, Wilcox MH, Rupnik M 2014. International Clostridium difficile animal strain collection and large diversity of animal associated strains. BMC Microbiol 14: 173.
Janezic S, Rupnik M 2010. Molecular typing methods for Costridium difficile: pulsed-field gel electrophoresis and PCR ribotyping. In: P Mullany, AP Roberts (Eds.), Clostridium difficile, methods and protocols, Springer Protocols - Methods in molecular biology (JM Walker, Series Ed.), vol. 646, Humana Press, London, p. 55-66.

Knight DR, Thean S, Putsathit P, Fenwick S, Riley TV 2013. Cross-sectional study reveals high prevalence of Clostridium difficile non-PCR ribotype 078 strains in Australian veal calves at slaughter. Appl Environ Microbiol 79: 2630-2635.

Koene MG, Mevius D, Wagenaar JA, Harmanus C, Hensgens MP, Meetsma AM, Putirulan FF, van Bergen MA, Kuijper EJ 2012. Clostridium difficile in Dutch animals: their presence, characteristics and similarities with human isolates. Clin Microbiol Infect 18: 778-784.

López-Ureña D, Quesada-Gómez C, Miranda E, Fonseca M, Rodríguez-Cavallini E 2014. Spread of epidemic Clostridium difficile NAP1/027 in Latin America: case reports in Panama. J Med Microbiol 63: 322-324.

Oliveira Junior CA, Silva ROS, Pires PS, Diniz AN, Lobato FCF 2016. Prevention of Clostridium difficile infection in hamsters using a non-toxigenic strain. Cienc Rural ID CR20150454.R2.

Quesada-Gómez C, Vargas P, López-Ureña D, Gamboa-Coronado M del M, Rodríguez-Cavallini E 2012. Community-acquired Clostridium difficile NAP1/027-associated diarrhea in an eighteen month old child. Anaerobe 18: 581-583.

Secco DA, Balassiano IT, Boente RF, Miranda KR, Brazier J, Hall V, dos Santos-Filho J, Lobo LA, Nouér SA, Domingues RM 2014. Clostridium difficile infection among immunocompromised patients in Rio de Janeiro, Brazil and detection of moxifloxacin resistance in a ribotype 014 strain. Anaerobe 28: 85-89.

Silva RO, D’Elia ML, Tostes Teixeira EP, Pereira PL, de Magalhães Soares DF, Cavalcanti AR, Kocuvan A, Rupnik M, Santos AL, Junior CA, Lobato FC 2014a. Clostridium difficile and Clostridium perfringens from wild carnivore species in Brazil. Anaerobe 28: 207-211.

Silva ROS, Almeida LR, Oliveira Junior CA, Soares DFM, Pereira PLL, Kocuvan A, Rupnik M, Lobato FCF 2014b. Carriage of Clostridium difficile in free-living South American coati (Nasua nasua) in Brazil. Anaerobe 2014: 99-101.

Silva ROS, Ribeiro MG, Palhares MS, Borges AS, Maranhão RP, Silva MX, Lucas TM, Olivo G, Lobato FC 2013a. Detection of A/B toxin and isolation of Clostridium difficile and Clostridium perfringens from foals. Equine Vet J 45: 671-675.

Silva ROS, Santos RL, Pires PS, Pereira LC, Pereira ST, Duarte MC, de Assis RA, Lobato FC 2013b. Detection of toxins A/B and isolation of Clostridium difficile and Clostridium perfringens from dogs in Minas Gerais, Brazil. Braz J Microbiol 44: 133-137.

Silva ROS, Vilela EG, Neves MS, Lobato FC 2014c. Evaluation of three enzyme immunoassays and a nucleic acid amplification test for the diagnosis of Clostridium difficile-associated diarrhea at a university hospital in Brazil. Rev Soc Bras Med Trop 47: 447-450.

Songer JG, Jones R, Anderson MA, Barbara AJ, Post KW, Trinh HT 2007. Prevention of porcine Clostridium difficile-associated disease by competitive exclusion with nontoxigenic organisms. Vet Microbiol 124: 358-361.

Songer JG 2010. Clostridia as agents of zoonotic disease. Vet Microbiol 140: 399-404.

Zhang K, Zhao S, Wang Y, Zhu X, Shen H, Chen Y, Sun X 2015. The non-toxigenic Clostridium difficile $\mathrm{CD} 37$ protects mice against infection with a BI/NAP1/027 type of $C$. difficile strain. Anaerobe 36: 49-52. 